\title{
13-143-12 輸入茶、輸入野菜中の環境放射能の定量 \\ The determination of radioactivity in imported teas and vegetables
}

\author{
○山口実穂、森田裕子、村上勲、本多照幸*、本間義夫、金澤秀子 \\ 共立薬科大学 \\ *武蔵工大・原研 \\ Miho Yamaguchi, Yuko Morita-Murase, Isao Murakami, Yoshio Homma, Hideko Kanazawa, \\ Kyoritsu University of pharmacy. \\ Teruyuki Honda, Musashi Institute of Technology.
}

\begin{abstract}
且的
セシウム-137 $\left({ }^{137} \mathrm{Cs}\right) ，$ ストロンチウム $-90\left({ }^{90} \mathrm{Sr}\right)$ は人 工放射性核種であり自然放射線源に比べ微量ではあるが、 ヨウ素-131 とともに被曝上重要な核種であるため、核実 験や原子力施設の事故などの評価で注目されている。日 本では検出限界末満まで下がっていたセシウム-137 が最 近、降下物、土壤、食品の一部から検出されたとの報告 がなされている。国内農作物の環境放射能濃度について は、その濃度が定期的に報告されているが、食材として の依存度が高いにも関わらず、輸入農作物の環境放射能 濃度については情報が少ないのが現状である。そこで本 報告では、主として中国から輸入された茶、野菜を中心 にこれらに含まれるセシウム-137，ストロンチウム-90 の定量結果について述べる。比較のため国内産について も検討を行った。
\end{abstract}

\section{試料調製}

中国産の茶、野菜等を乾燥後、るつぼに入れ、電気炉を 用いて $450^{\circ} \mathrm{C} て ゙ 十$ 数時間かけて灰化した。灰化後の試料を 細粉し、円筒プラスティック製容器（内径 $4.5 \mathrm{~cm}$ 、高さ $6.5 \mathrm{~cm})$ に移し、セシウム-137 濃度の測定試料とした。 その後、さらにこの試料を $500^{\circ} \mathrm{C}$ で灰化し、シュウ酸塩法 による化学分離操作を行い、放射平衡に達する 2 週間以 上放置しストロンチウム-90 濃度測定試料とした。

\section{測定方法}

セシウム-137：ゲルマニウム半導体検出器を用いたガン マ線スペクトロメトリにより、セシウム-137 測定用に調 整した試料の $y$ 線測定を行った。まず、GCW1521 Canberra 社のゲルマニウム半導体検出器で $5 \times 10^{4}$ 秒/試 料の測定を行った。有意な測定值 (光電ピーク計数率が 30 以上）を示す試料について、GMX-15190-P Ortec 社の検 出器を用いて $2.5 \times 10^{5}$ 秒の測定を行った。検出効率は、標
準線源を用い、さらに試料充填高による試料中での $\gamma$ 線 減弱（自己吸収）を考慮し補正した。ガンマ線スペクト ロメトリで得られた試料中セシウム -137 の $662 \mathrm{keV}$ のピ 一ク面積から、30 以上を示す光電ピーク計数率 (net cps) を有意な計数率として、自己吸収を補正した検出効率を 用いセシウム-137 の濃度（Bq/ $/ \mathrm{kg} ）$ を算出した。 ストロンチウム 90 : 液体シンチレーションスペクトロメ 一タによる改良積分計数法を用いてストロンチウム-90 試料と平衡状態にあるイットリウム-90を定量した。すな わち、あらかじめトリチウム標準線源による積分バイア ス曲線を $\mathrm{Bq}$ 值に達するまで外挿し、液体シンチレーショ ンスペクトロメータの真の “ゼロ”であるゼロしきい值 (zero detection threshold) をまず求め、次に試料を測 定し、積分バイアス曲線をゼロしきい值に外挿すること で、ストロンチウム -90 濃度を求めた。

\section{測定機器}

・ゲルマニウムガンマ線スペクトロメトリ

1. ゲルマニウム半導体検出器 : GMX-15190-P (Ortec) 相対効率 $20.4 \%$ 、分解能 $1.9 \mathrm{keV}$ in $1.33 \mathrm{MeV}$

MCA : 7700 (Seiko-EG\&G)

2. ゲルマニウム半導体検出器: GCW1521 (Canberra) 相対効率 $16.1 \%$ 、分解能 $1.9 \mathrm{keV}$ in $1.33 \mathrm{MeV}$

MCA : 35 プラス (Canberra)

・液体シンチレーションスペクトロメータ

Packard Tri-Carb 3170TR/SL

\section{結果および考察}

表 1 に、茶、そば粉、しいたけ中のセシウム -137 濃度、 表 2 に野菜中のセシウム-137 濃度の測定結果を示す。 4 種類の中国産の茶について、セシウム -137 濃度は ND $\sim 0.52 \pm 0.05 \mathrm{~Bq} / \mathrm{kg}$ の範团であった。日本茶からも同程度 検出された。抽出物である市販品のボトル入り中国茶は 


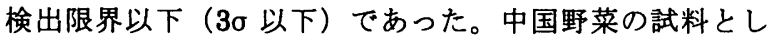
て多くは冷凍食品を用いたが、これらは、検出限界以下 （30以下）であった。冷凍食品は洗浄等の前処理を受け ているため、セシウム-137 が低浱度となった可能性もあ る。しいたけは冷凍食品からも検出された（ND〜 $0.18 \pm 0.03 \mathrm{~Bq} / \mathrm{kg}$ )。ストロンチウム-90については、中国 茶、中国野菜等、数種類の測定を行ったが、これらにつ

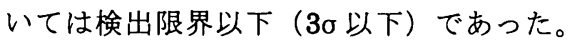

以上の結果は直ちに問題となる莀度ではないが、様々な 食物を介して人体に蓄積されるため、国内産農作物のみ ならず、食材として依存度が高い輸入農作物の定期的な 測定が今後必要であろう。

また、最近の日本におけるセシウム-137, ストロンチウ ム-90 検出の原因として、大陸から飛来する黄砂との関連 が考えられている。黄砂の防止策も重要な課題であると 考える。
表1 茶、そば羒、しいたけ中のセシウム -137 濃度

\begin{tabular}{|c|c|c|c|}
\hline \multicolumn{2}{|c|}{ 試料名（産地） } & 検体数 & 平均値 (最小一最大) $\mathrm{Bq} / \mathrm{kg}$ \\
\hline \multirow[t]{5}{*}{ 茶 } & 中国緑茶 (中国) & 1 & ND \\
\hline & プーアール茶 (中国) & 1 & ND \\
\hline & ジャスミン茶(中国) & 2 & $0.26(N D-0.52 \pm 0.05)$ \\
\hline & 中国茶(抽出物)* & 3 & ND \\
\hline & 日本茶(日本) & 2 & $0.49(0.24 \pm 0.08-0.73 \pm 0.12)$ \\
\hline \multirow[t]{3}{*}{ そば粉 } & （中国） & 2 & $0.06(N D-0.12 \pm 0.04)$ \\
\hline & （北米） & 1 & $0.087 \pm 0.027$ \\
\hline & （日本） & 5 & $0.024(N D-0.12 \pm 0.02)$ \\
\hline \multirow[t]{3}{*}{ しいたけ } & （中国） & 1 & $0.18 \pm 0.03$ \\
\hline & (中国)** & 3 & $0.05(N D-0.16 \pm 0.02)$ \\
\hline & （日本） & 1 & $0.98 \pm 0.03$ \\
\hline
\end{tabular}

*ボトル入り市販品

**冷凍食品
表 2 野菜中のセシウム -137 浱度

\begin{tabular}{|l|c|c|}
\hline 試料名(産地) & 検体数 & 濃度 Bq/kg \\
\hline 小松菜(中国)* & 1 & $\mathrm{ND}$ \\
きぬさや(中国)* & 1 & $\mathrm{ND}$ \\
オクラ(中国)* $^{*}$ & 1 & $\mathrm{ND}$ \\
枝豆(中国)* $^{*}$ & 1 & $\mathrm{ND}$ \\
らつかせい(中国) & 1 & $\mathrm{ND}$ \\
白ねき(中国)* & 1 & $\mathrm{ND}$ \\
玉ねき(中国)* & 1 & $\mathrm{ND}$ \\
ショウガ(中国) & 1 & $\mathrm{ND}$ \\
にんにく(中国) & 1 & $\mathrm{ND}$ \\
ごぼう(中国) & 2 & $\mathrm{ND}$ \\
にんにくの芽(中国) & 1 & $\mathrm{ND}$ \\
長いも(中国) & 1 & $\mathrm{ND}$ \\
\hline
\end{tabular}

*冷凍食品 